\title{
Artisans' Knowledge and Perception on Hand-Dug Well Waterborne Related Diseases in Dutse Mechanic Village North-West, Nigeria
}

\section{1*ADELEYE, AO; ${ }^{2}$ ORIFAH, MO; ${ }^{1}$ AMOO, AO; ${ }^{1}$ IJANU, EM; ${ }^{1}$ SHUAIBU, SJ; ${ }_{1,3}^{3}$ HASSAN, A}

\author{
${ }^{I}$ Department of Environmental Sciences, Faculty of Science, Federal University Dutse, Nigeria. \\ ${ }^{2}$ Department of Agricultural Economics and Extension, Faculty of Agriculture, Federal University Dutse, Nigeria. \\ ${ }^{3}$ Department of Public Health, Ministry of Health Jigawa State, Nigeria. \\ *Corresponding Author Email: adeniyi.adeleye@fud.edu.ng; adeniyiadeleye80@gmail.com \\ Tel: +2348124215650
}

\begin{abstract}
This study was conducted to assess the knowledge and perception of artisans in Dutse mechanic village regarding hand-dug well waterborne related diseases with the aid of questionnaire. Data were collected from seventy (70) respondents on selected personal attributes and analyzed using descriptive statistics. All the respondents indicated that there are two (2) wells in the mechanic village. The study revealed that a high proportion (80\%) of the respondents actively repair automobiles while $4.3 \%$ take part in various trading activities. Majority (70\%) of the respondents indicated that microbial pollutants can cause waterborne diseases while minority $(30 \%)$ of the respondent reported a contrary view. Respondents $(7.1 \%)$ reported to have been diagnosed of waterborne diseases while majority $(92.9 \%)$ of the respondents reported that they have not been diagnosed of any water borne disease. However, respondents diagnosed of waterborne diseases specified diarrhoea (1.4\%), typhoid (1.4\%) and urinary tract infection (4.3\%). It can be concluded that the artisans are lackadaisical towards ensuring hygienic maintenance of the wells as clearly revealed in the results obtained in this study. It is recommended that the wells in the village should be covered when not in use coupled with drawing water with a well-kept fetcher devoid of microbial loads.
\end{abstract}

\section{DOI: https://dx.doi.org/10.4314/jasem.v22i10.13}

Copyright: Copyright $\odot 2018$ Adeleye et al. This is an open access article distributed under the Creative Commons Attribution License (CCL), which permits unrestricted use, distribution, and reproduction in any medium, provided the original work is properly cited.

Dates: Received: 10 September 2018; Revised: 12 October 2018; Accepted: 29 October 2018

Keywords: Hand-dug well, microbial pollutants, waterborne diseases, mechanic village.

Availability and proximity of potable water for human consumption are important attributes that reveal adequate wellbeing of humans in their immediate environment. According to Tya et al. (2012), water remains one of the most important resources and the principal needs of man in his immediate environment. The consumption of poor and contaminated water can pose adequate health problems capable of threatening human life (Mustapha and Yusuf, 1999). Tya et al. (2012), has indicated that the pollution of any groundwater sources can be traced to emanate from domestic, agricultural and industrial wastes. This implies that hand-dug well being one of the recognised groundwater sources is susceptible to being polluted.

According to Ayantobo et al. (2012), hand-dug wells serve as a panacea to the provision of cheap and low technology water to the numerous challenges linked with rural and urban supply of water. However, these authors coupled with Tya et al. (2012), did submit that hand-dug wells are far more susceptible to contamination than those categorized as deeper boreholes. Adeyemi et al. (2007) has reportedly attributed the contamination of water supplies caused by bacteria, viruses, heavy metals, nitrates and salts to inadequate treatment and indiscriminate disposal of human, livestock, industrial wastes and overutilization of water resources that are limited. It has been established by Murcott (2007); Oluwasanya et al. (2011), that hand-dug wells could be categorized as; protected, un-protected or semi-protected.

These authors further reiterated that a protected well is equipped with manual or motorized pump, concrete lining and apron, head wall, cover and drainage. It imperative to state here that the two hand-dug wells present in Dutse mechanic village fall short of the descriptions of these authors thereby rendering it susceptible to pollution and necessitating the need to elicit information from the artisans in the village regarding their knowledge and perception about well waterborne related diseases. This study was therefore aimed at assessing the knowledge and perception of

*Corresponding Author Email: adeniyi.adeleye@fud.edu.ng; adeniyiadeleye80@gmail.com

Tel: +2348124215650 
artisans in Dutse mechanic village regarding hand-dug well waterborne related diseases.

\section{MATERIALS AND METHOD}

Description of Study Area: According to Map (2011), Dutse is the capital city of Jigawa State North-Western Nigeria and also the headquarters of the 28 local government areas that make up the state. Dutse is located at $11.76^{\circ}$ North latitude, $9.34^{\circ}$ East longitude and 460 meters elevation above the sea level.

It is a small city that has about 17,129 inhabitants. Dutse derives its name from the rocky topography peculiar to the area. Different forms of rocks can be seen widely spread across the town mostly igneous in nature. Dutse and its environs are well known for date palm trees of different varieties. With availability of agrarian land, the inhabitants of Dutse are predominantly farmers; other occupations typical to rural area are also available among the populace.

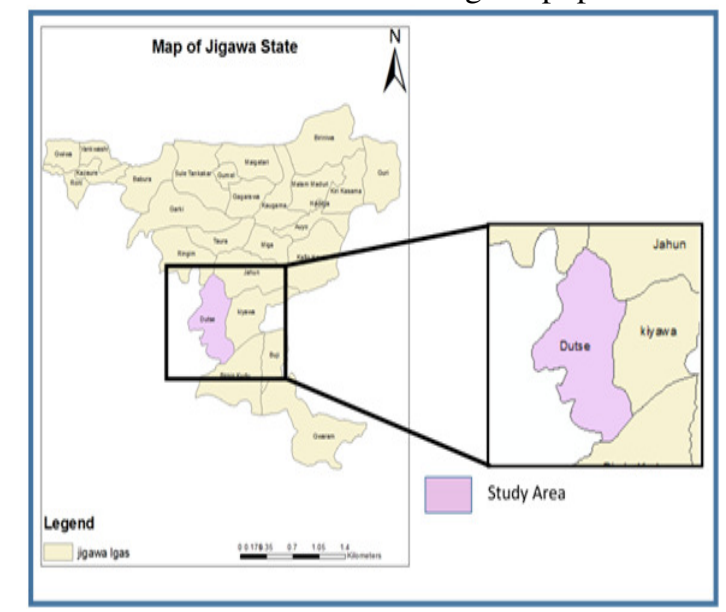

Fig 1: Map of the study area (geographic information system)

Study Design: A survey study involving the use of structured questionnaires was adopted to elicit information from the artisans in the mechanic village on their knowledge and perception regarding well waterborne related diseases.

Sample Size Determination: A personal interview conducted with Mallam Bala (Head of the Artisans in the village) established the total number of registered artisans in the mechanic village as two hundred and twenty two (222). This led to sampling 30\% (69) artisans which were interviewed with the aid of structured questionnaire to get background information on their knowledge and perception regarding waterborne related diseases. The number of the artisans interviewed was made up to seventy (70) with a view to rounding it up to a whole number.
Data Analysis: Data collected from this study were analyzed using computer Statistical Package for Social Scientists (SPSS) at $95 \%$ probability level of significance. The results of the questionnaires were summarized using frequencies and percentages as done by Amori and Makinde, (2012).

\section{RESULTS AND DISCUSSION}

Socio-demographic Characteristics of the Artisans: It can be seen in Table 1 that male $(77.1 \%)$ and female $(22.9 \%)$ actively took part in this study. Respondents $(35.7 \%),(54.3 \%)$ and $(10 \%)$ fall in between the age ranges of 18-27 years, 28-37 years and 38-47 years respectively. It can equally be deduced from Table 1 that singles $(61.4 \%)$, married $(31.4 \%)$, divorced $(2.9 \%)$ and widowed $(4.3 \%)$ made up the marital status of the respondents. In terms of religions practiced by the respondents, $60 \%$ of the respondents are Muslims while $40 \%$ are Christians. Respondents $(80 \%)$ are involved in automobile repairs. Respondents $(4.3 \%)$ indicated that they trade (sale of automobile parts and accessories) in the village while respondents (15.7\%) specified that they are involved in other activities in the village apart from automobile repairs and trading (Table 1$)$.

Table 1: Selected socio-demographic attributes of the respondents $(\mathrm{n}=70)$

\begin{tabular}{ll}
\hline Variables & Percentages (\%) \\
\hline Sex & \\
Male & 77.1 \\
Female & 29.9 \\
Age range & \\
18-27 years, & 35.7 \\
28-37 years & 54.3 \\
38-47 years & 10 \\
Marital Status & \\
Singles & 61.4 \\
Married & 31.4 \\
Divorced & 2.9 \\
Widowed & 4.3 \\
Religion & \\
Muslim & 60 \\
Christianity & 40 \\
Respondents major occupation & \\
Automobile repairs & 80 \\
Trading & 4.3 \\
Other activities & 15.7 \\
\hline
\end{tabular}

Respondents' Knowledge on Well Water Pollution: Respondents $(91.4 \%)$ did indicate that the activities being carried out on daily basis in the village do pollute the environment while $8.6 \%$ indicated that the activities do not pollute the environment. It can be deduced from Figure 2 that respondents $(84.3 \%)$ are aware that the well water can be polluted by microbial and other environmental pollutants while respondents $(15.7 \%)$ do not know that the well water can be polluted by any form of pollutants. Majority (70\%) of the respondents indicated that pollutants can cause 
waterborne diseases while minority (30\%) of the respondent claimed that pollutants cannot cause waterborne diseases. These results indicate that minority of the respondents are not aware of the fact that contaminants play a huge role in the contamination of water meant for human consumption, The findings are in agreement with the study of Al-Medhawi et al. (2005), about how microbial contaminants do play a huge role in the contamination of water meant for human consumptions.

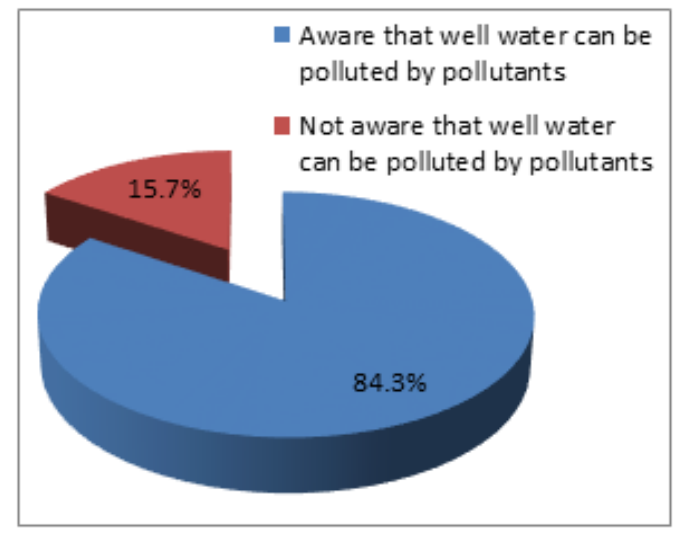

Fig 2: Respondents awareness of possible well water pollution

Respondents' Perceived Pollution Types and Sources in the Village: In terms of types of pollution in the village, respondents $(5.7 \%)$ chose air pollution while $58.6 \%$ indicated land pollution and respondents $(35.7 \%)$ indicated both options as sources of environmental pollution in the village (Table 2 ).

Table 2: Respondents' perceived pollution types and sources

\begin{tabular}{|c|c|}
\hline Variables & $\begin{array}{l}\text { Frequencies } \\
(\%)\end{array}$ \\
\hline \multicolumn{2}{|l|}{ Pollution types } \\
\hline Air & 5.7 \\
\hline Land & 58.6 \\
\hline Both & 35.7 \\
\hline \multicolumn{2}{|l|}{ Pollution source } \\
\hline Spent engine oil & 40 \\
\hline Littering, loitering of refuse and sewage & 8.6 \\
\hline Both & 51.4 \\
\hline $\begin{array}{l}\text { Possibility of pollutants contaminating } \\
\text { groundwater }\end{array}$ & \\
\hline Yes & 78.6 \\
\hline No & 21.4 \\
\hline
\end{tabular}

Respondents (40\%) indicated that the main source of pollution in the village is from spent engine oil and $8.6 \%$ indicated littering, loitering of refuse and sewage, whereby $51.4 \%$ of the respondents indicated both options for littering, loitering of refuse and sewage and that of spent engine oil (Table 2). Respondents (78.6\%) believed that these pollutants do seep underground and contaminate ground water while respondents $(21.4 \%)$ indicated that the pollutants do not seep underground and contaminate the ground water in the process (Table 2).

All the respondents indicated that there are two (2) wells in the mechanic village. Respondents (35.7\%) indicated that 20-40 people do visit the village on daily basis. Respondents (50\%) indicated that $40-80$ people do visit the village on daily basis while $14.3 \%$ believed that the range of people that visit the village on a daily basis is between 80-120. The variations in their observation on the number of people that visit the village on daily basis may be due to the number of patronage they get individually.

Respondents $(92.9 \%)$ revealed that hand-dug well is the main source of water in the village while respondents $(2.9 \%)$ indicated borehole as the main source of water. However, $4.3 \%$ of the respondents indicated both hand-dug well and borehole as the main source of water in the village (Table 3 ). These results are in contrast to the study of Odjegba et al. (2015), where all the respondents could adequately differentiate each of the various sources of water available to them from one another compared to this current study in which respondents $(4.3 \%)$ could not differentiate between a typical hand-dug well and borehole.

Respondents (57.1\%) indicated that 20-40 people make use of the well on daily basis, $41.4 \%$ indicated 40-60 people as those that make use of the well on daily basis while $1.4 \%$ of the respondents indicated otherwise (Table 3). $2.9 \%$ of the respondents indicated drinking purpose as the intended usage of the water from the wells while $38.6 \%$ indicated that they do use the water from the wells to wash plates and cook while majority $(58.6 \%)$ of the respondents indicated that they use the water to perform ablution and other activities like bathing, washing and so on (Table 3 ).

Table 3: Respondents' perceived patronage level, available water source and purpose of fetching water in the mechanic village

\begin{tabular}{ll}
\multicolumn{1}{c}{$(\mathrm{n}=70)$} \\
\hline Variables & $\begin{array}{l}\text { Percentage } \\
(\%)\end{array}$ \\
\hline $\begin{array}{l}\text { Level of patronage } \\
\text { 20-40 people }\end{array}$ & 35.7 \\
$\begin{array}{l}\text { 40-60 people } \\
\text { 80-120 people }\end{array}$ & 50 \\
Water source in the village & 14.3 \\
$\begin{array}{l}\text { Well } \\
\text { Borehole }\end{array}$ & 92.9 \\
$\begin{array}{l}\text { Both } \\
\text { Purpose of fetching water } \\
\text { from the well }\end{array}$ & 4.3 \\
$\begin{array}{l}\text { Drinking } \\
\text { Washing of plates and cooking }\end{array}$ & 38.6 \\
$\begin{array}{l}\text { Ablution, bathing and other } \\
\text { activities }\end{array}$ & 58.6 \\
\hline
\end{tabular}


Response on Treatment of Well Water before Usage: As shown in Figure 3, respondents $(5.7 \%)$ indicated that the water is treated before usage while majority $(94.3 \%)$ of the respondents indicated that the water is not subjected to any form of treatment before usage.

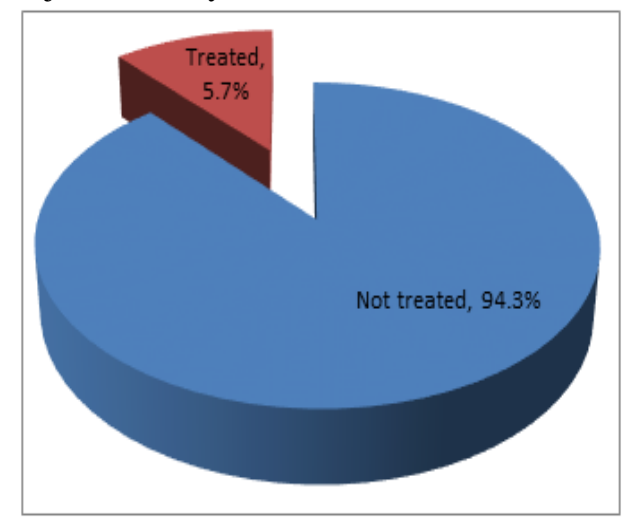

Fig 3: Respondents response to treatment of well water before use

Majority $(88.6 \%)$ of the respondents are used to fetching water from the well while respondents $(11.4 \%)$ reported that they do not fetch water from the two wells. This result is a clear indication that majority of the respondents utilize the water from the wells. The massive reliance on the two wells present is not only peculiar to the mechanic village alone for water supply as Alabi-Aganaba and Osagbemi (2005); Aderibigbe, et al. (2008) indicated in their respective studies that a lot of people in their respective study areas had epileptic supply of water thereby prompting perpetual search for water and might go without water for days.

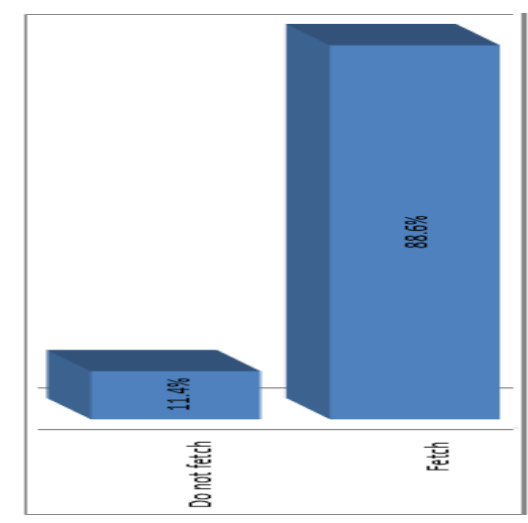

Fig 4: Respondents' response to fetching water from the wells

Water Fetching Receptacles Adopted and Consumption by Respondents: Respondents (4.3\%) use their personal fetcher and $82.9 \%$ of the respondents use the general fetcher to draw water from the wells. Majority (75.7\%) of the respondents indicated that they drink water fetched from the wells while $23.3 \%$ of the respondents claimed that they have never drunk water fetched from the well before (Figure 5).

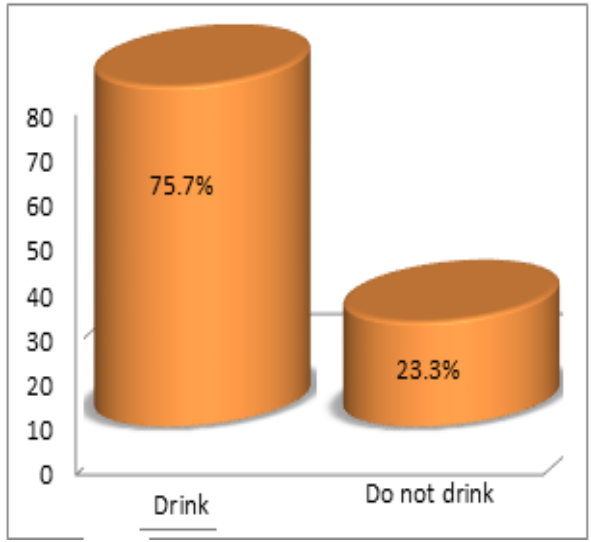

Fig 5: Water consumption percentage by the respondents

Response on Diagnosis of Waterborne Related Diseases: Respondents (7.1\%) reported that they have been diagnosed of waterborne diseases while majority $(92.9 \%)$ of the respondents reported that they have not been diagnosed of any waterborne disease. This contradiction owing to the majority $(75.7 \%)$ of the respondents that admittedly drink the well water might have been caused by the fact that respondents knew, for instance the importance of using personal fetchers, covering of well and clearing the dumpsites close to the wells, therefore they could not tell the interviewer something that would make them feel ashamed of themselves. Again, the denial of waterborne related diseases that majority $(92.9 \%)$ of the respondents claimed in this current study can be attributed to the 'God forbid' syndrome described by Oluwasanya (2009) in which people of African descents tend to deny the obvious fact that they have certainly gone down or are currently suffering from a particular disease.

However, respondents that have been diagnosed of waterborne diseases reportedly specified diarrhoea $(1.4 \%)$, typhoid $(1.4 \%)$ and urinary tract infection (UTI) $(4.3 \%)$. These results are in agreement with the submissions of Noi (2008); Okonko, et al., (2008); O'Reilly et al. (2008); Vivas et al. (2010); Odjegba et al. (2015) that reportedly established the consequences of drinking polluted water to the advent of waterborne bacterial diseases and viral infections; polio, hepatitis, cholera, typhoid, diarrhea, stomach cramps and so on. Interestingly, the results in this current study are in contrast with the findings of Noi (2008) in which at least $30.4 \%$ of the respondents diagnosed of waterborne related diseases could not name any waterborne diseases. Even though minority (7.1\%) of the respondents did indicate going down with the specified water related illnesses as against the huge number of respondents $(75.7 \%)$ that reportedly drink water fetched from the wells, the revelation of these 
water borne diseases may be linked with consumption of water from the wells.

Conclusion: Assessment of the level of knowledge and perception of the artisans as regards waterborne related diseases led to the conclusion that artisans in the study area have sufficient knowledge about sources of pollution. However, it can be concluded that the knowledge is not properly utilized for the maintenance of sanitary systems in the village which was very poor during the conduct of this study. Their lackadaisical attitude towards the maintenance of the wells indicates that they are exposed to the negative effects that might arise as a result.

Acknowledgements: The authors are grateful to the head of the artisans in Dutse mechanic village, Jigawa state, Nigeria for his unalloyed cooperation and for encouraging all the artisans to actively participate most especially all the respondents that were interviewed in the village in the course of this study.

\section{REFERENCES}

Aderibigbe, SA; Awoyemi, AO; Osagbemi, AO (2008). Availability, Adequacy and Quality of Water Supply in Ilorin Metropolis, Nigeria. European Journal of Scientific Research. 23, no.4 (2008):528 - 536.

Adeyemi, O; Oloyede, OB; Oladiji, AT (2007). Physicochemical and Microbial Characteristics of Leachate-Contaminated Groundwater. Asian $J$. Biochem, 2 (5): 343-348.

Alabi - Aganaba, D; Osagbemi, GK (2005). Sources and Utilization of Water in two Selected Communities in Ilorin East Local Government Area of Kwara State. African Journal of Clinical Experimental Microbiology 1, no.7 (2005): 11-16.

Al-Medhawi, E.; Briggs, C.; Keane, S (2005). Household Hygiene Improvement Survey in Yemen: Knowledge, Practices, and Coverage of Water Supply, Sanitation and Hygiene; US Agency for International Development (USAID): Washington, DC, USA

Amori, AA; Makinde, AA (2012). Evaluation of Access to Public Water Supply in Two Major Cities in Nigeria. American Journal of Environmental Engineering. 2 (6): 148-151.

Ayantobo, OO; Oluwasanya, GO; Idowu OA; Eruola, AO (2012). Water Quality Evaluation of Hand-dug Wells in Ibadan, Oyo State, Nigeria. Hydrology for Disaster Management. Special Publication of the Nigerian Association of Hydrological Sciences. 231-239.

Maps (2011). Dutse Maps - road map, satellite view and street view. Available at https://www.mapsstreetview.com/Nigeria/Dutse/. (Retrieved on August 30th, 2018).
Murcott, S (2007). Water Sources (improved and unimproved) and Water Supply. Available at http://ocw.mit.edu/NR. (Retrieved on September 12th 2018).

Mustapha, S; Yusuf, MI (1999) A Text Book on Hydrology and Water Resources. Jenas Prints and Publications Company, Abuja. Nigeria.

Noi, H (2008). For a Clean, Hygienic and Healthy Environment for All Vietnamese Children. A Summary of National Baseline Survey on Environmental Sanitation and Hygiene Situation in Vietnam. Available at www.un.org.vn/en/publications/doc_details/44summary-national-survey-on-sanitation-and-hygienein-viet-nam.html?tmpl=component. (Retrieved on September 12th, 2018).

Odjegba EE; Idowu, OA; Ikenweiwe, NB; Martins, O; Sadeeq, AY (2015). Public Perception of Potable Water Supply in Abeokuta South West, Nigeria. J. Appl. Sci. Environ. Manage. 19 (1): 5-9.

Okonko, IO; Adejoye, OD; Ogunnusi, TA; Fajobi, EA; Shittu, OB (2008). Microbiological and Physicochemical Analysis of Different Water Samples used for Domestic Purposes in Abeokuta and Ojota, Lagos State, Nigeria. African Journal of Biotechnology 7 (5): $617-621$.

O’Reilly, CE; Freeman, MC; Ravani, M; Migere, J; Mwaki, A; Ayalo, M; Ombeki, S; Hoekstra, RM; Quick, R (2008). The impact of a School-based Safe Water and Hygiene Programme on Knowledge and Practices of Students and their Parents: Nyanza Province, Western Kenya. Epidemiol. Infect. 136: 80-91.

Oluwasanya, GO (2009). Better Safe than Sorry: Towards Appropriate Water Safety Plans for Urban Self Supply Systems in developing countries. PhD. Thesis, Cranfield University, UK, 459 pp.

Oluwasanya, GO; Smith, J; Carter, R (2011). Self -Supply Systems: Urban Dug Wells in Abeokuta, Nigeria, Journal of Water Science and Technology: Water Supply. 11 (2): 172 - 178

Tya, TSK; Umaru, AB; Barmamu, BR (2012). Bacteriological Analysis of Hand-Dug Well Water in Demsa Local Government Area, Nigeria. International Refereed Journal of Engineering and Science (IRJES. 1 (4): 28-31.

Vivas, A; Aboset, N; Kumie, A; Berhane, Y; Williams, MA (2010). Knowledge, Attitudes and Practices (KAP) of Hygiene among school children in Angolela, Ethiopia. J. Prev. Med. Hyg. 51: 73-79. 